\title{
FENOMENA PENDIDIKAN SEX-CLASS DALAM MEMBANGUN KARAKTER SISWA BERWAWASAN GENDER PADA SEKOLAH MUSLIM
}

\author{
Syamsurijal, Trisakti Handayani, Nurbani Yusuf \\ FKIP Universitas Muhammadiyah Malang, Indonesia \\ Email: syamsurija1998@gmail.com
}

\begin{abstract}
ABSTRAK
Penelitian ini bertujuan untuk menjelaskan (1) pelaksanaan pendidikan sex-class dalam membangun karakter siswa berwawasan gender, (2) faktor-faktor penghambat pelaksanaan pendidikan sex-class dalam membangun karakter siswa yang berwawasan gender, dan (3) solusi mengatasi hambatan pelaksanaan pendidikan sex-class dalam membangun karakter siswa yang berwawasan gender. Jenis penelitian yang digunakan adalah penelitian kualitatif dengan metode fenomenologi, yaitu metode yang berupaya untuk memahami makna yang sesungguhnya atas suatu pengalaman, menekankan pada kesadaran (intentional of consciousness). Kemudian, pengumpulan data diperoleh melalui kegiatan observasi, wawancara, dan pemanfaatan dokumen. Sementara, data hasil penelitian di analisis dengan alur, yaitu pengumpulan data, reduksi data, penyajian data, dan penarikan kesimpulan. Adapun hasil penelitian menunjukan, bahwa (1) pendidikan sex-class berfungsi untuk menyalurkan nilai kesetaraan gender, menjawab stereotip masyarakat yang menafsirkan siswi sebagai individu yang lemah, juga membangun paradigma yang tidak memandang siswi sebagai sub ordinat siswa yang berlandaskan pada nilai agama dan kesopanan, (2) hambatan dalam pelaksanaan pendidikan sex-class ialah pengetahuan, pemahaman, sikap guru serta peran sekolah yang absolut, dan (3) solusi dalam mengatasi berbagai hambatan ialah dengan melakukan sosialisasi yang berkelanjutan.
\end{abstract}

Kata Kunci: Pendidikan Sex-class; Karakter; Gender; Sekolah Muslim

\section{ABSTRACT}

This study aims to explain (1) the implementation of sex-class education in building the character of gender-minded students, (2) inhibiting factors for the implementation of sex-class education in building the character of students who are gender-minded, and (3) solutions to obstacles to sex education -class in building the character of students who are gender minded. The type of research used is qualitative research with phenomenology methods, namely methods that attempt to understand the true meaning of an experience, emphasizing awareness (intentional of consciousness). Then, data collection is obtained through observation, interviews, and document utilization. Meanwhile, the research data is analyzed by flow, namely data collection, data reduction, data presentation, and conclusion drawing. The results of the study show that (1) sex-class education serves to channel the value of gender equality, respond to the stereotypes of people who interpret female students as weak individuals, also build a paradigm that does not view female students as student subordinates based on religious values and politeness, (2) obstacles in the implementation of sex-class education are knowledge, understanding, attitudes of teachers and absolute school roles, and (3) solutions to overcome various obstacles is to carry out ongoing socialization.

Keywords: Sex-class Education, Character, Gender, Muslim School 


\section{PENDAHULUAN}

Koentjaraningrat (2015:11) menjelaskan bahwa kebudayaan merupakan akar kata dari bahasa Sanskerta, Buddhayah, bentuk jamak dari Buddhi yeng berarti akal dan budi, dengan demikian kebudayaan dapat diartikan sebagai keseluruhan sistem gagasan, tindakan, dan hasil karya manusia dalam rangka kehidupanya yang kemudian dijadikan milik bersama melalui proses belajar. Gender adalah pemilahan peran antara laki-laki dan perempuan dalam kehidupan sosial merupakan bagian dari kebudayaan. Gender mencakup pandangan, gagasan, teknologi, pembangunan, pemberdayaan, dan bahkan perlakuan-perlakuan yang bias gender (Handayani \& Sugiati, 2017:7-8). Isu gender adalah asumsi atau persoalan tentang ketidakadilan hubungan sosial antara laki-laki dan perempuan berdasarkan peran jenis kelamin.

Menurut Burke (2015:75) gender adalah konsepsi penggolongan yang menfokuskan pada pembagian peran sosial antara laki-laki (maskulin) dan perempuan (feminim) di dalam masyarakat. Sedangkan, menurut Handayani dan Sugiarti (2017:3) gender adalah sifat yang melekat pada laki-laki dan perempuan yang terbentuk dari faktor-faktor sosial maupun budaya, sehingga melahirkan anggapan tentang peran sosial dan budaya yang pantas atau baik untuk dilakukan oleh laki-laki ataupun perempuan. Selanjutnya, Jones dkk (2016:287) mengatakan terdapat perbedaan secara sosiologis antara seks dan gender. Pembedaan ini dimaksudkan untuk mempertegas batas antara apa yang bisa dan yang tidak bisa diubah oleh reformasi sosial dan politik. Istilah seksual merujuk kepada perbedaan-perbedaan kromosom dan faali yang berkaitan dengan fungsi-fungsi reproduksi laki-laki dan perempuan, sedangkan gender merujuk kepada kategori-kategori yang dikonstruksi secara sosial terkait maskulinitas dan feminitas. Pembedaan ini dimaksudkan untuk menjelaskan bahwa relasi-relasi sosial antara laki-laki dan perempuan menciptakan gender secara tidak setara. Memperlakukan hukum seolah berasal dari biologi untuk membenarkan praktikpraktik budaya yang melestarikan dominasi laki-laki terhadap perempuan.

Masyarakat cenderung menganggap konstruksi yang ada sebagai kodrat tanpa melihat ciri emosional dan psikologis, akibatnya mempengaruhi keyakinan serta budaya masyarakat tentang bagaimana lakilaki dan perempuan bertindak. Masyarakat sebagai kelompoklah yang menciptakan pembagian gender untuk menentukan apa yang dianggap sebagai sebuah keharusan untuk dilakukan dan tidak seharusnya dilakukan. Kemudian, pembagian peran ini diwariskan dari satu generasi kepada generasi selanjutnya, sehingga melahirkan keyakinan bahwa pembagian peran tersebut adalah alamiah, normal, dan merupakan kodrat dari Tuhan (Handayani \& Sugiarti, 2017:8).

Ketidakadilan gender (gender inequalities) atas salah-satu jenis kelamin, seperti perempuan seringkali berangkar dari serangkaian hambatan berdasarkan adat kebiasaan dan hambatan hukum, yang membatasi masuknya serta keberhasilan perempuan dengan apa yang disebut sebagai dunia publik, karena masyarakat mempunyai keyakinan yang keliru bahwa perempuan secara alamiah tidak secerdas dan sekuat laki-laki (Handayani \& Sugiarti, 2017:13-14). Masyarakat meminggirkan perempuan dari akademi, forum, pendidikan, politik, dan ekonomi. Akibat dari politik peminggiran ini, potensi sesungguhnya dari perempuan tidak terpenuhi. Menurut Jones dkk (2016:291295) Kuatnya budaya patriarki seringkali membekukan peran-peran sosial, ekonomi, dan politik yang cenderung memarjinalkan atau bahkan diskrimantif terhadap salah satu jenis kelamin. Pandangan yang menganggap kaum perempuan adalah sub 
ordinat kaum laki-laki, telah menimbulkan dampak negatif mulai dari lemahnya partisipasi dalam pengambilan keputusan, sempitnya akses pendidikan, sampai dengan kurang berdayanya menghadapi berbagai tindak kekerasan yang dialami oleh perempuan. Dikotomi semacam ini menimbulkan lahirnya ideologi gender yaitu bagaiman laki-laki dan perempuan didefinisikan, dinilai, dipersepsikan dan diharapkan untuk bertingkah laku. Ideologi ini terus berkembang dan disosialisasikan terus menerus dari generasi ke generasi melalui keluarga, sekolah, agama, bahkan negara (Syamsiah, 2014:273-274).

Beberapa temuan penelitian menunjukan adanya indikasi ketidakadilan gender, seperti hasil penelitian yang dilakukan oleh Murnalungito (2016:9) dengan judul "Diskriminasi Gender Terhadap Peserta Didik Perempuan Yang Hamil Peserta Di Jenjang Pendidikan Sekolah Menengah Atas", menunjukan bahwa terdapat perlakuan diskriminasi gender, ketika peserta didik perempuan diwajibkan menandatangani surat pernyataan yang dibuat oleh pihak sekolah, agar mengundurkan diri dengan kesadarannya bila diketahui hamil. Sedangkan, peserta didik laki-laki tidak diberikan surat pernyataan serupa bila peserta didik lakilaki menghamili peserta didik perempuan, dengan kesadarannya harus mengundurkan diri. Diskriminasi gender juga terjadi ketika, peserta didik perempuan tidak diberikan kebebasan untuk memilih untuk cuti hamil atau tidak. Selanjutnya, penelitian yang dilakukan Suardi (2016:44) dengan judul "Implikasi SosialDiskriminasi Gender(Studi Tentang Gender Di Kampung Bungung Katammung Kabupaten Bantaeng)", hasil penelitian menunjukan terdapat perlakuan diskriminasi gender yang ada di Kampung Bungung Katammung Kabupaten Bantaeng yaitu marjinalisasi, subordinasi, streotipe, Violence (kekerasan), Double Burden (beban ganda) pada kaum perempuan.
Beberapa penelitian diatas membuktikan bahwa terjadi ketidakadilan, diskrimanasi, dan bahkan sub ordinasi gender baik dilingkungan masyarakat maupun di lingkup pendidikan formal.

Kesadaran dan pengetahuan masyarakat terhadap gender masih kurang, di mana senantiasa terdapat bias gender dalam meperlakukan laki-laki dan perempuan. Masyarakat seringkali mengkotak-kotakan hal-hal apa saja yang pantas dan tidak pantas, cocok atau tidak cocok untuk lakilaki dan perempuan. Hal ini seringkali memarginalkan kaum perempuan tetapi tidak jarang juga memarginalkan kaum laki-laki. Proses sosialisasi gender sebagai bagian dari kebudayaan, seharusnya perlu dilakukan baik di lingkungan masyarakat maupun sucara khusus di sekolah. Sekolah adalah lembaga penyaluran nilai-nilai dan norma-norma yang berlaku dalam masyarakat, termaksut nilai dan norma gender. Nilai dan norma tersebut disalurkan secara lugas maupun secara tersembunyi (bias), baik melalui teks-teks tertulis, dalam buku pelajaran, maupun dalam perlakuan-perlakuan yang mencerminkan nilai dan norma gender. Pesan-pesan yang dikemukakan dalam bentuk benda atau simbol, seperti gambar dalam buku cerita atau buku-buku sekolah lebih berarti bagi anak-anak daripada pesan yang disampaikan secara verbal (Dirman \& Juarsih, 2014:15). Sekolah dapat bertindak menjadi penguat atau pendekontruksi bahkan pembentuk kemapanan nilai gender yang sudah dimiliki anak sebelumnya.

Uraian di atas menunjukan betapa stategisnya lingkungan sekolah sebagai lembaga penyaluran dan penanaman nilai. Hasil observasi awal yang dilakukan di lokasi penelitian, yaitu SD Darul Muhmin Khuan Kalong Thailand, menunjukan adanya perlakuan-perlakuan yang mencerminkan kesetaraan terhadap siswa dan siswi. Hal tersebut terlihat dari pemberian kesempatan yang sama untuk 
mengembangkan diri semaksimal mungkin dalam mencapai prestasi yang sama tanpa mempermasalahkan jenis kelamin. Padahal sistem pembelajaran yang digunakan sekolah berbasis pada pembagian kelas menurut kesamaan jenis kelamin (sexclass), yang tentu bermuara pada lahirnya pendidikan yang bersifat eksklusif. Artinya, pendidikan yang bersifat tertutup atau terpisah antara satu dengan yang lainya (siswa dan siswi).

\section{METODE}

Berdasarkan jenis pendekatan, secara umum penelitin dibagi ke dalam dua jenis, yaitu penelitian kuantitatif dan kualitatif. Menurut Moleong (2014:6) Penelitian kualitatif adalah penelitian yang dimaksudkan untuk memahami subyek penelitian dari segi persepsi, perilaku, motivasi, dan tindakan Penelitian ini menggunakan jenis penelitian kualitatif dengan pertimbangan, bahwa permasahaan dalam penelitian ini memerlukaan model pengamatan bukan pada pengangkaan. Kemudian, pendekatan kualitatif lebih mudah jika dihadapkan pada kenyataan, emosional, dan psikologis dengan informan, sehingga dapat diperoleh data yang mendalam.

Adapun metode yang digunakan adalah metode fenomenologi, yaitu metode yang berupaya untuk memahami makna yang sesungguhnya atas suatu pengalaman, menekankan pada kesadaran yang disengaja atas pengalaman (intentional of consciousness), serta memahami pengalaman sebagai suatu yang mengandung nilai (luar dan dalam) yang berbasis ingatan, makna, dan gambaran (Gunawan, 2013:7172). Pemilihan metode fenomenologi sebagai metode penelitian didasarkan pada pertimbangan, bahwa permasalahan yang dikaji menyangkut makna atas pengalaman hidup yang dialami oleh individu. Kemudian, fenomenologi mempelajari paradigma dan keyakinan langsung dari individu (first-hand experiences) sebagai subyek sampai pada tataran keyakinan. Selanjutanya, diarahkan untuk memperoleh kejelasan atas fenomena yang dialami oleh individu.

\section{HASIL DAN PEMBAHSAN}

Data dalam penelitian dianalisis dengan merujuk pada model analisis menurut Miles dan Huberman (2014:14) yang meliputi proses reduksi data yaitu tahap penyaringan, pemangkasan, dan pengelompokan data, kemudian data selanjutnya dipaparkan lalu diverifikasi, dan dibuat kesimpulan. Kemudian, hasil analisis dibahas serta dijelaskan lebih lanjut dengan menggunakan teori nurture dan teori equilibrium. Adapun beberapa sub bab yang akan dibahas ialah sebagai berikut:

\section{Pelaksanaan Pendidikan Sex-class dalam Membangun Karakter Siswa Berwawasan Gender}

Pendidikan sex-class merupakan bagian dari pendidikan berbasis pada kesetaraan gender, karena berorientasi pada pemenuhan kesempatan dan hak yang sama bagi laki-laki maupun perempuan. Kemudian, teori nurture adalah teori yang beranggapan bahwa perbedaan relasi gender bukan ditentukan oleh faktor biologis, melainkan dibentuk serta dikonstruksikan secara sosial dan budaya oleh masyarakat. Teori ini memperkuat penjelasan sebelumnya bahwa pembiasaan yang dilakukan secara tidak sengaja, tidak disadari, dan berulang-ulang telah melahirkan pembakuan peran serta sifat. Teori nurture menolak pemberian label peran sebagai bagian dari kodrat dari Tuhan, sehingga harus diterima dan dilakukan. Penggolongan peran laki-laki dan perempuan merupakan hasil dari usaha yang direncanakan guna membedakan keduanya dalam posisi serta peranan sosial. Fenomena munculnya ketidaksetaraan gender dalam lingkungan pendidikan 
terutama di tingkat pendidikan dasar tidak terlepas dari cara dan muatan materi yang diajarkan. Materi yang terdapat dalam buku-buku teks pelajaran di Sekolah Dasar memiliki kecenderungan yang menggambarkan pembakuan peran gender, misal Ibu yang digambarkan untuk memainkan peran domestik, seperti memasak, mengasuh anak, dan membersihkan rumah. Sementara Bapak digambarkan memilki peran publik, misalnya pekerja kantor. Secara tidak sadar bahwa muatan materi pendidikan yang demikian itu, berimplikasi pada perluasan stereotip dalam masyarakat. Penjelasan di atas, sejalan dengan pernyataan Ulya (2013:12) bahwa materi yang diajarkan pada pendidikan Sekolah Dasar cenderung menunjukan kekentalan perbedaan gender.

SD Darul Muhmin merupakan sekolah berbasis Muslim (Islam) tingkat dasar yang melaksanakan pendidikan dengan model sex-class. Pendidikan sexclass merupakan pendidikan yang membagi, mengelompokan serta memisahkan siswa dan siswi ke dalam kelas tertentu berdasarkan pada kesamaan jenis kelamin, sehingga terdapat kelas siswa, juga kelas siswi. Pelaksanaan pendidikan sex-class di SD Darul Muhmin tidak berlaku secara keseluruhan pada setiap tingkatan atau jenjang kelas, melainkan hanya berlaku pada kelas tingkatan 4, tingkatan 5, dan tingkatan 6. Pelaksanaan pendidikan sex-class merujuk pada nilai-nilai yang dibenarkan secara agama sebagai basis sekolah dan norma kesopanan dalam kebudayaan Thailand. Pelaksanaan pendidikan dengan model ini, tentu melahirkan pendidikan yang bersifat eksklusif, yaitu pendidikan yang tertutup antara satu dengan yang lain. Namun, pelaksanaan pendidikan sex-class di SD Darul Muhmin justru mencerminkan pendidikan yang terbuka bahkan mengarah pada pembentukan wawasan gender. Secara eksplisit tidak terdapat aturan yang menjadi pedoman dalam pelaksanaan pendidikan sex-class dalam membangun karakter siswa berwawasan gender, namun secara implisit terkandung di dalam pilar visi dan misi sekolah. Pelaksaan pendidikan sex-class di SD Darul Muhmin bertujuan untuk membentuk karakter siswa yang berwawasan, menjaga batasan pergaulan siswa dan siswi sesuai ajaran agama dan kebudayaan, juga berfungsi memudahkan dalam memberikan perlakuan pada saat kegiatan belajar mengajar berlangsung.

Pelaksanaan pendidikan sex-class merupakan wadah untuk mengekspresikan kesetaraan gender di lingkungan pendidikan, sekaligus untuk menjawab kecenderungan adanya pandangan kebanyakan orang (masyarakat) yang menafsirkan siswi sebagai individu yang lemah, penyabar, dan lebih menggunakan perasaan. Sementara, siswa dianggap sebagai individu yang tegas, keras, dan berani. Akibatnya, secara sadar atau tidak ketika siswa dan siswi ditempatkan dalam satu kelas terjadi pertentangan karakteristik. Pengelompokan dan pemisahan kelas antara siswa dan siswi justru memberikan kesempatan kepada siswa atatupun siswi untuk tumbuh secara optimal. Uraian tersebut diperkuat dengan pernyataan Ahsan (2016:3) bahwa pemisahan kelas berdasarkan jenis kelamin akan meningkatkan daya fokus siswa dan siswi. Selain itu, pengelompokan dan pemisahan kelas siswa dan siswi jauh lebih memudahkan guru dalam meberikan perlakuan berupa aksi dan sanksi yang berhubungan dengan permasalahan gender (Rusyidiyah, 2016:41).

Pelaksanaan pendidikan sex-class di SD Darul Muhmin dirancang kearah desain pembelajaran yang memiliki muatan nilai dan sikap yang peka terhadap keadilan dan kesetaraan gender. Sebelumnya, telah dijelaskan bahwa terjadi pertentangan karakteristik ketika siswa dan siswi disatukan ke dalam satu kelas yang sama. Untuk itu, SD Darul Muhmin memadukan atau menyelaraskan kurikulum sekolah, 
guru, media pengajaran, desain pembelajaran, lingkungan kelas, dan sekolah secara kolektif, kooperatif, dan eksploratif dalam mengembangkan serta membentuk sikap siswa untuk menghargai keadilan dan kesetaraan gender. Pertengan karakter dimaksudkan terlihat ketika kegiatan belajar mengajar berlangsung, misalnya dalam materi pelajaran Pengetahuan Sosial mengenai hak dan kewajiban anggota keluarga disebutkan: "keluarga pak nana hidup rukun, semua tahu hak dan kewajibannya, pak nana bekerja mencari nafkah, pak nana seorang guru, tiap hari ia bekerja keras .... Ibu Ida ibu rumah tangga, tiap hari ia mengurus keluarga, ia memasak, mencuci dan mengatur rumah, $\mathrm{Bu}$ Ida bekerja tak kenal lelah, ia tahu tugasnya" (Ulya, 2013:19). Sebenarnya materi tersebut, merupakan perluasan stereotip dalam masyarakat terhadap kegiatan yang diperankan siswa (laki-laki) dan siswi (perempuan). Implikasi dari model kurikulum tersebut menunjukkan adanya pembakuan peran sosial antara kaum perempuan dan kaum laki-laki. Kemudian, hal lain dapat ditemukan ketika dalam kelas yang tidak dipisah guru meberikan hukuman kepada siswa lebih keras dibandingkan kepada siswi. Pemberian hukuman tersebut semakin memperkuat indikasi siswi sebagai makhluk yang lemah. Oleh karena itu, karakter yang berwawasan pada kesetaraan adalah alsan mengapa dilaksanakanya pendidikan sex-class di SD Darul Muhmin.

Selanjutnya, di luar kegiatan belajar mengajar pelaksanaan pendidikan sexclass dalam membangun karakter siswa yang berwawasan gender terlihat pada salah satu kegiatan yang menjadi agenda tahunan sekolah, yaitu pameran akademik. Kegiatan ini meliputi pembacaan (pidato) Bahasa Thailand, Bahasa Inggris, Bahasa Melayu, bercerita, mendongeng, gambar, melukis, panggung teknolohi, kaligrafi, memasak, wirausaha, dan pameran kreasi siswa. Kegiatan ini selain diwajibkan untuk diikuti oleh siswa dan siswi, juga menjadi tempat pertemuan dengan orang tua atau wali siswa. Kegiatan memasak dan wirausaha merupakan kegiatan yang mengarah pada pembangunan paradigma siswa mengenai stereotip siswi sebagai ratu domestik. Hal tersebut dapat dipahami, bahwa dua kegiatan tersebut biasanya identik dengan siswi (perempuan), namun berbeda dengan praktik yang terjadi di SD Darul Muhmin yang justru tidak membatasinya menjadi kegiatan bagi siswi semata, siswa bahkan juga ikut andil didalamnya. Kegiatan ini justru menanamkan pemahaman bahwa memasak bukanlah peran, tugas, dan tanggung jawab siswi (perempuan). Sehingga, dengan kegiatan ini secara tidak langsung membentuk pola pikir, cara pandang, dan persepsi terhadap stereotip yang telah membudaya dalam masyarakat.

Berdasarkan penjelasan di atas, dapat disimpulkanbahwapelaksanaanpendidikan sex-class dalam membangun karakter siswa berwawasan gender di SD Darul Muhmin telah mewujudkan kesempatan pendidikan yang memperhatikan kesetaraan gender. Kemudian, memacu peningkatan mutu dan efisiensi pendidikan melalui pemberdayaan potensi perempuan secara optimal serta memperkecil ketimpangan gender. Artinya, teori nurture sejalan untuk memperjelas bahwa konstruksi sosial budaya merupakan suatu tindakan yang direncanakan dan bukan kodrat dari Tuhan, sehingga melahirkan pemahaman, wawasan, dan pengetahuan yang keliru tentang tentang pembagian peran antara laki-laki dan perempuan. Namun, tetap berlandaskan pada nilai-nilai Agama dan budaya.

\section{Hambatan Pelaksanaan Pendidikan Sex-class dalam Membangun Karakter Siswa Berwawasan Gender}

Kurangnyakesadaran dan terbatasnya pengetahuan masyarakat terhadap gender senantiasa melahirkan perilaku bias gender 
dalam memperlakukan laki-laki dan perempuan. Akbitnya, seringkali terjadi pengotakan peran yang patas, baik, cocok, dan ideal untuk dilakukan. Pemolaan ini dilakukan sejak usia dini sampai dewasa, sehingga terkesan yang demikian itu harus diterima dan dilakukan. Bias gender terjadi ketika terjadi dominasi dari salah satu jenis kelamin yang menyebabkan timbulnya peran gender (role gender). Kemudian, teori equilibrium adalah teori yang menekankan pada konsep kemitraan dan keharmonisan dalam hubungan antara laki-laki dan perempuan secara seimbang, sehingga membentuk pola hubungan komplomenter. Artinya, antara laki-laki dan perempuan bukan berebut dominasi, tetapi saling melengkapi aktualisasi masing-masing.

Menurut teori equilibrium, dalam mewujudkan kesetaraan gender perlu memperhatikan masalah kontekstual, yaitu tempat dan waktu dan situasi (kondisi atau keadaan). Kesetaraan tidak dapat diukur secara matematis atau keseimbangan jumlah dan tidak bersifat universal. Merujuk pada kosep tersebut, bahwa kesetaraan tidak dimaksudkan sebagai kesejajaran antara laki-laki dan perempuan. Melainkan, kesetaraan diharapkan agar tidak terjadi pembiasaan-pembiasaan yang berorientasi pada perlakuan yang tidak berkeadilan. Artinya, kesetaraan dalam teori equilibrium menjadikan laki-laki dan perempuan sebagai satu kesatuan yang saling melengkapi kekurang dan kelebihan masing-masing. Perlu dipertegas, kesetaraan menurut teori equilibrium antara wilayah, daerah satu bisa saja berbeda dengan daerah lainya, hal tersebut bergantung kapan dan bagaimana itu terjadi.

Uraian sebelumnya memperjelas, bahwa faktor-faktor yang menjadi hambatan dalam pelaksanaan pendidikan sex-class dalam membangun karakter siswa berwawasan gender di SD Darul Muhmin ialah pengetahuan, pemahaman, dan sikap guru. Pengetahuan tentang gender yang terbatas menjadi faktor utama yang menjadi penghambat terlaksananya pendidikan sex-class dalam membangun karakter siswa berwawasan gender. Pengetahuan yang kurang berakibat pada pemahaman dan sikap guru dalam memperlakukan siswa dan siswi. Artinya, guru belum memahami secara menyeluruh esensi siswa dan siswi sebagai mitra belajar yang saling melengkapi kelebihan serta kekurangan. Hal tersebut, terlihat dari sikap guru yang melakukan penunjukan kepada siswa untuk menjadi pemimpin upacara (ijkamna sautung) hanya melihat pada ciri fisik, seperti suara lantang, berani, kuat, dan tahan panas, padahal terdapat juga siswi yang memiliki ciri seperti itu, setidaknya, siswi ditunjuk sebagi wakil pemimpin.

Faktor lain berupa basis sekolah sebagai sekolah Muslim (Islam) dengan peran yang absolut. Peran ini melahirkan pemahaman yang multitafsir, artinya terdapat anggapan bahwa sekolah mampu mendevinisikan kegiatan yang berorientasi pada gender, namu nyatanya sekolah belum mampu memberikan penjelasan kegiatan yang berdasarkan agama, budaya, dan wawasan gender. Hal tersebut dikarenakan sekolah belum memiliki wawasan lengkap bagaimana memandang siswa dan siswi sebagai sisi komplementer yang utuh. Disamping itu, gaya komunikasi sekolah yang terbatas pada musyawarah juga perlu dipertimbangkan model lain agar maksud dan tujuan pendidikan berwawasan gender dapat dipahami oleh seluruh elemen sekolah. Teori ini telah menguraikan bahwa kemitraan dan keharmonisa di suatu tempat pada satu waktu bisa saja berbeda, namun kontek ketidakadilan cenderung universal sehingga tidak dapat dipungkiri teori ini sekaligus memperlihatkan masih terjadinya paktek bias gender yang dilakukan dalam lingkup sekolah. Ketidakadilan muncul ketika terjadi dominasi salahsatu jenis kelamin, missal laki-laki. 
Sehingga, secara otomatis menimbulkan terjadinya marginalisasi, sub ordinasi, dan kesenjangan gender.

\section{Solusi Mengatasi Hambatan Pelaksanaan Pendidikan Sex-class dalam Membangun Karakter Siswa Berwawasan Gender}

Persoalan gender bukanlah persoalan baru dalam kajian ilmu sosial, hukum, dan agama. Kajian mengenai gender dalam banyak hal masih terjadi berbagai ketimpangan yang berimbas pada ketidakadilan gender. Isu kesetaraan gender muncul setelah menguatnya kesadaran publik bahwa terjadi kesenjangan antara lakilaki dan perempuan dalam pengelenggaraan kehidupan bermasyarakat. Kesenjangan yang dimaksud adalah perbedaan peran dan fungsi, sehingga menimbulkan perbedaan gender (gender difference). Menurut teori equilibrium bahwa gender difference atau perbedaan gender bukan merupakan suatu masalah sepanjang tidak menimbulkan ketidakadilan gender (gender inequilities). Namun, realitas yang terjadi perbedaan gender telah menimbulkan berbagai ketidakadilan. Hal tersebut, dapat dilihat pada bagaimana terjadinya pengotakan, pengelompokan, bahkan pembakuan peran dan tugas antara laki-laki dan perempuan dalam kehidupan msyarakat. Teori equilibrium menjelaskan relasi antara laki-laki harus kompromistis dan berjalan seimbang. Hubungan yang komplementer antara laki-laki dan perempuan diharapkan mampu mengurangi berbagai ketidakadilan peran gender.

Berdasarkan pemaparan di atas, diperoleh kesimpulan bahwa SD Darul Muhmin dalam memberikan kesempatan, hak, dan perlakuan terhadap siswa dan siswi memperhatikan aspek kebutuhan serta kesesuain secara agama dan budaya. Hal tersebut, sesuai dengan konsep penerapan dari kompromi equilibrium yang memeperhatikan masalah kontekstual dan situasional. Kemudian, sosialisasi merupakan upaya yang dilakukan oleh sekolah dalam menyelaraskan pemahaman tentang wawasan gender. Sosialisasi dilakukan dalam bentuk musyawarah, terbagi dalam dua waktu, yaitu pada pagi hari dan sore hari. Sosialisasi menjadi wadah bagi sekolah untuk menyamakan pemahaman, pandangan, danpersepsicivitas sekolah. Selanjutnya, sekolah menyediakan ruang tanya jawab guna memperluas wawasan gender tentang kesetaraan. Sehingga, civitas menyadarinya sebagai sebuah kebutuhan. Artinya, teori equilibrium, sejalan dengan proses penyelesaian berbagai hambatan dalam pelaksanaan pendidikan sex-class dalam membangun kerakter siswa berwawasan gender di SD Darul Muhmin.

\section{SIMPULAN}

Berdasarkan pada hasil penelitian yang dibahas pada bab sebelumnya, maka dapat sisimpulkan sebagai berikut: SD Darul Muhmin merupakan salah satu sekolah muslim tingkat dasar di daerah Khuan Kalong, Thailand yang menerapkan sistem pendidikan sex-class. Dasar yang menjadi pedoman pelaksanaan pendidikan sex-class di SD Darul Muhmin adalah visi dan misi sekolah. Selanjutnya, pelaksanaan pendidikan sex-class di SD Darul Muhmin tidak diberlakukan pada semua tingkatan kelas, akan tetapi hanya berlaku untuk kelas pada tingkatan atas yaitu kelas tingkatan 4 sampai kelas tingkatan 6. Pelaksanaan pendidikan sex-class didasarkan pada nilai agama dan kesopanan dalam kebudaya Thailand. Selain berfungsi untuk memjaga batas pergaulan siswa dan siswi, pendidikan sex-class juga berfungsi untuk memudahkan memberikan perlakukan dalam pembelajaran. Pendidikan sexclass bukan merupakan bagian dari bentuk diskrminasi gender terhadap salah satu jenis kelamin, akan tetapi pendidikan sexclass adalah instrument untuk membentuk karakter siswa yang berwawasan pada kesetaraan gender. Hal tersebut dapat 
dilihat dari model pembelajaran, muatan materi bahan ajar, dan cara sekolah memperlakukan siswa dan siswi secara setara yang berdasarkan pada aspek kemampuan, antara siswa dan siswi diberikan kesempatan yang sama untuk terlibat baik sebagai anggota ataupun ketua dalam berbagai kegiatan. Namun, demikian pendidikan sex-class yang diterapkan tetap berpedoman pada nilai agama dan batasbatas kesopanan masyarakat Thailand.

Adapun beberapa faktor yang menjadi hambatan dalam pelaksanaan pendidikan sex-class di SD Darul Muhmin ialah pengetahuan, pemahaman, dan sikap guru, pengetahuan tentang gender yang terbatas menjadi faktor utama yang menjadi penghambat terlaksananya pendidikan sex-class dalam membangun karakter siswa berwawasan gender. Pengetahuan yang kurang berakibat pada pemahaman dan sikap guru dalam memperlakukan siswa dan siswi. Faktor lain berupa basis sekolah sebagai sekolah muslim (islam) dengan peran yang absolut, melahirkan pemahaman yang multitafsir. Artinya, tidak semua dapat memberikan penjelasan kegiatan yang berdasarkan agama, budaya, dan wawasan gender. Disamping itu, gaya komunikasi sekolah yang terbatas pada musyawarah juga perlu dipertimbangkan model lain agar maksud dan tujuan pendidikan berwawasan gender dapat dipahami oleh seluruh elemen sekolah.

Solusi yang dilakukan oleh pimpinan sekolah SD Darul Muhmin dalam mengatasi berbagai hambatan pada proses pelaksanaan pendidikan sex-class dalam membangun karakter siswa berwawasan gender adalah dengan melakukan sosialisasi yang berkelanjutan. Sosialisasi menjadi instrumen kunci dalam memberikan pemahaman, pengetahuan, dan pembenahan tentang arti serta nilai kesetaraan. Sosialisasi dilakukan dalam bentuk musyawarah, terbagi dalam dua waktu, yaitu pada pagi hari dan sore hari. Sosialisasi menjadi wadah bagi sekolah untuk menyamakan pemahaman, pandangan, dan persepsi civitas sekolah. Selanjutnya, sekolah menyediakan ruang tanya jawab guna memperluas wawasan gender tentang kesetaraan. Sehingga, civitas menyadarinya sebagai sebuah kebutuhan.

\section{DAFTAR PUSTAKA}

Burke, Peter. 2015. Sejarah dan Teori Sosial (Volume 2). Jakarta: Yayasan Pustaka Obor Indonesia

Dirman,. \& Juarsih, Cicih. 2014. Pengembangan Potensi Didik dalam Rangka Implementasi Standar Proses Pendidikan Siswa. Jakarta: PT. Rineka Cipta

Gunawan, Imam. 2013. Metode Penelitian Kualitatif: Teori dan Praktek. Jakarta: Bumi Aksara

Handayani, Trisakti., \& Sugiarti. 2017. Konsep dan Teknik Penelitian Gender. Malang: UMM Press

Jones, Pip., Bradbury, Liza., \& Boutillier, Shaun Le. 2016. Pengantar TeoriTeori Sosial (Volume 2). Jakarta: Yayasan Pustaka Obor Indonesia

Koentjaraningrat. 2015. Pengantar Ilmu Antropologi. Jakarta: PT. Rineka Cipta

Miles, Mathew B., Michael Huberman, dan Johnny Saldana. 2014. Qualitative Data Analysis-Third Edition. London: Sage Publication Ltd.

Moleong, Lexy J. 2014. Metode Penelitian Kualitatif. Bandung: PT. Remaja Rosdakarya

Murnalungito, Destya Nanda. 2017. Diskriminasi Gender Terhadap Peserta Didik Perempuan yang Hamil Peserta di Jenjang Pendidikan Sekolah Menengah Atas. Jurnal Hukum, (Online), No. HK11028 (1): 1-9, (http://e-journal.uajy.ac.id/ id/eprint/11695) Diakses pada 8

Desember 2018 
Suardi. 2016. Implikasi Sosial Diskriminasi Gender (Studi tentang Gender di Kampung Bungung Katammung Kabupaten Bantaeng). Jurnal Sosiologi Pendidikan Humanis, (Online), No. 1 (1): 40-46, (http://journal2.um.ac. $\mathrm{id} /$ index.php/jsph/issue/view/266), Diakses pada 8 Desember 2018

Syamsiah, Nur. 2014. Wacana Kesetaraan Gender. Jurnal Sipakalebbik, (Online), No. 3 (1): 265-301, (http://journal.uinalauddin.ac.id/index.php/sipakalebbik/ article/view/278), Diakses pada 16 Desember 2018
Ulya, Inayatul. 2013. Pendidikan Berbasis Kesetaraan Gender. Jurnal studi islam dan sosial, (Online) No 2 (15): 147170, (http://journal.walisongo.ac.id/ index.php/wahana/article/view/536), Diakses pada 9 Januari 2019 